DOI: https://doi.org/10.24144/2409-6857.2018.2(52).206-211

УДК 336.71

Шевчук Н.С., Коверда А.В.

\title{
МЕТОДИЧНІ АСПЕКТИ АНАЛІЗУ КРЕДИТОСПРОМОЖНОСТІ ПОЗИЧАЛЬНИКІВ БУДІВЕЛЬНОГО СЕКТОРА
}

\begin{abstract}
Стаття присвячена пошуку підходів щедо удосконалення методики оцінки кредитоспроможності підприємств будівельного сектору економіки, який $\epsilon$ одним $з$ найскладніших для кредитування. Досліджено сучасну нормативну базу для розрахунку інтегрального показника фінансового стану боржника-юридичної особи, запропоновано доповнити контент аналітичних критеріїв кредитоспроможності кількісними та якісними показниками оцінки сочіальної відповідальності бізнесу.
\end{abstract}

Ключові слова: кредитоспроможність, будівельний сектор економіки, фінансові коефіцієнти, ділова активність, соиіальна відповідальність бізнесу.

Постановка проблеми. Будівельний бізнес $є$ високомаржинальним, але вплив світової фінансової кризи на українську економіку, економічні коливання та пов'язаний $з$ цим ризик виявляють проблему підтримання кредитоспроможності для позичальників будівельного сектору, який характеризується використанням значних обсягів кредитних ресурсів. Вирішення аналітичних завдань 3 оцінки економічної заможності потенційних позичальників будівельного сектору 3 позиції кредитоспроможності дозволяє кредитним установам приймати ефективні управлінські рішення щодо надання позик й отримання доходів від успішних кредитних операцій. Для будівельних компаній України важливим чинником економічного розвитку $\epsilon$ рівень взаємозв'язків підприємства 3 суспільством та впливає на репутацію потенційних позичальників. На сучасному етапі кредитна діяльність банків ускладнюється відсутністю поглибленої та відпрацьованої методики оцінки кредитоспроможності позичальників будівельного сектору, тому актуальним завданням є конкретизація методичних підходів управлінського та фінансового аналізу господарської діяльності підприємств будівельної галузі. Доповнення методики оцінки рівня кредитоспроможності будівельних підприємств критеріями дотримання соціальної відповідальності сприятиме ефективному управ-

(C) Шевчук Ніна Сергіївна, к.е.н., доц., Одеський національний економічний університет, м. Одеса тел: +380504921988, e-mail: shevchuknina23@gmail.com Коверда Анатолій Васильович, к.е.н., доц., Одеський національний економічний університет, м. Одеса тел.: +380970970003,e-mail: anatolii.koverda@ gmail.com лінню кредитними ризиками.

Аналіз останніх досліджень i публікацій. Дослідження вітчизняними та закордонними вченими питань, пов'язаних із ризиком у банківській діяльності та оптимізацією методики оцінки фінансового стану підприємств та їх кредитоспроможності, знайшли відображення у працях І.А. Бланка, В.В. Вітлинського, А.В.Грачова, О.В. Дзюблюка, О.Д.Заруби, А.М. Мороза, В.I Терехіна, О.В.Пєрнарев-ського, М.І.Савлука та ін.

Питанням впровадження соціально відповідального відношення до ведення бізнесу присвячено праці Д. Баюри, О.Ю. Березіної, Т.Р. Власової, К.В. Плахотнікової, В.А. Євтушенко та ін.

Аналіз досліджень показав пріоритетність використання фінансових показників в існуючих методиках оцінки кредитоспроможності позичальників, але для якісної оцінки та моніторингу кредитоспроможності позичальників будівельного сектору доповнення методики показниками аналізу соціальної відповідальності будівельного бізнесу сприятиме зниженню кредитного ризику банківських установ.

Формулювання цілей статті. Метою статті $\epsilon$ дослідження теоретичних та методичних аспектів аналізу будівельних підприємств як основи оцінки рівня кредитоспроможності позичальників будівельного сектору.

Опис основного матеріалу дослідження. Ефективна діяльність будівельних підприємств та ï стійкий стан на ринку підсилює впевненість банку у своєчасному та повному поверненні позики. Відповідно чинних стандартів НБУ, кредитоспроможність визначається наявністю у позичальника (контрагента банку) передумов для 
проведення кредитної операції i його спроможністю повернути борг у повному обсязі та в обумовлені договором строки [1]. Рекомендовані критерії визначення кредитоспроможності позичальників характеризують його здатність своєчасно розраховуватися за раніше одержаними кредитами, його поточне фінансове становище, спроможність у разі потреби мобілізувати кошти 3 різних джерел i забезпечити оперативну конверсію активів у ліквідні кошти [1].

Застосування рекомендованих критеріїв визначення кредитоспроможності на практиці потребує врахування галузевих особливостей потенційних позичальників. Відповідно цього зверенемо увагу на чинний порядок проведення оцінки фінансового стану потенційного бенефіціара інвестиційного проекту [2]. Як бачимо, до моделі розрахунку інтегрального показника фінансового стану підприємств будівельного сектору крім рекомендованих НБУ фінансових коефіцієнтів (коефіцієнт покриття, коефіцієнт фінансової незалежності, коефіцієнт рентабельності активів за чистим прибутком), внесено коефіцієнти: покриття необоротних активів власним капіталом, коефіцієнт рентабельності продажів за фінансовими результатами від операційної діяльності, коефіцієнт рентабельності операційної діяльності за EBITDA.

Відзначимо, що суттєво критерії оцінки кредитоспроможності нормативної бази висвітлюють два підходи: оцінка ділової активності за звітний період та оцінка фінансового стану на дату складання фінансової звітності (таблиця 1).

Таблиця 1

Система фінансових показників для розрахунку кредитоспроможності будівельного підприсмства*

\begin{tabular}{|c|c|c|c|}
\hline $\begin{array}{l}№ \\
3 / \Pi\end{array}$ & Показники & Характеристика & Формула розрахунку \\
\hline \multicolumn{4}{|c|}{ Показники ділової активности } \\
\hline \multirow[t]{2}{*}{1.} & \multirow[t]{2}{*}{ Покриття боргу $\left(\mathrm{K}_{\Pi}\right)$ [1] } & \multirow{2}{*}{$\begin{array}{c}\text { Спроможність обслуговування } \\
\text { боргу доходами від основного } \\
\text { виду діяльності }\end{array}$} & $\begin{array}{c}\text { Коротко- та довгострокові } \\
\text { зобов'язання }\end{array}$ \\
\hline & & & $\begin{array}{c}\text { Чистий дохід від реалізованої } \\
\text { продукції }\end{array}$ \\
\hline \multirow[t]{2}{*}{2.} & \multirow{2}{*}{$\begin{array}{l}\text { Рентабельність активів }\left(\mathrm{P}_{\text {a }}\right)[1] \\
\text { або } \\
\text { Коефіцієнт рентабельності } \\
\text { активів за чистим прибутком } \\
\left(\mathrm{K}_{8}\right)[2]\end{array}$} & \multirow[t]{2}{*}{$\begin{array}{c}\text { Ефективність використання } \\
\text { активів підприємства }\end{array}$} & $\begin{array}{c}\text { Чистий фінансовий } \\
\text { результат/операційний результат }\end{array}$ \\
\hline & & & Валюта балансу (актив) \\
\hline \multirow[t]{2}{*}{3.} & \multirow{2}{*}{$\begin{array}{l}\text { Покриття фінансових витрат } \\
\text { за результатами операційної } \\
\text { діяльності }\left(\kappa_{\phi}\right)[1]\end{array}$} & \multirow{2}{*}{$\begin{array}{c}\text { Спроможність фінансування } \\
\text { неопераційних витрат за } \\
\text { результатами операційної } \\
\text { діяльності }\end{array}$} & Операційний прибуток (збиток) \\
\hline & & & Фінансові витрати \\
\hline \multirow[t]{2}{*}{4.} & \multirow{2}{*}{$\begin{array}{l}\text { Період повного обороту } \\
\text { активів підприємства, дні }\left(\mathrm{K}_{\mathrm{a}}\right) \\
\text { [1] }\end{array}$} & \multirow{2}{*}{$\begin{array}{c}\text { Характеризує швидкість } \\
\text { обороту всіх активів } \\
\text { підприємства }\end{array}$} & Валюта балансу х 365 \\
\hline & & & $\begin{array}{c}\text { Чистий дохід від реалізованої } \\
\text { продукції }\end{array}$ \\
\hline \multirow[t]{2}{*}{5.} & \multirow{2}{*}{$\begin{array}{l}\text { Період, необхідний для } \\
\text { повного оновлення поточних } \\
\text { активів }\left(\mathrm{K}_{\text {па }}\right)[1]\end{array}$} & \multirow{2}{*}{$\begin{array}{c}\text { Характеризує швидкість } \\
\text { обороту поточних активів } \\
\text { підприємства }\end{array}$} & Поточні активи \\
\hline & & & $\begin{array}{c}\text { Чистий дохід від реалізованої } \\
\text { продукції }\end{array}$ \\
\hline \multirow[t]{4}{*}{6.} & \multirow{4}{*}{$\begin{array}{l}\text { Достатність робочого } \\
\text { капіталу }\left(K_{\mathrm{pk}}\right)[1]\end{array}$} & \multirow{4}{*}{$\begin{array}{c}\text { Характеризує тривалість } \\
\text { фінансового циклу } \\
\text { підприємства }\end{array}$} & Запаси \\
\hline & & & $\begin{array}{c}\text { Собівартість реалізованої } \\
\text { продукції } \\
+ \\
\text { Дебіторська заборгованість }\end{array}$ \\
\hline & & & $\begin{array}{c}\text { Чистий дохід від реалізованої } \\
\text { продукції } \\
- \\
\text { Кредиторська заборгованість }\end{array}$ \\
\hline & & & $\begin{array}{c}\text { Собівартість реалізованої } \\
\text { продукції }\end{array}$ \\
\hline
\end{tabular}


Продовження табл. 1

\begin{tabular}{|c|c|c|c|}
\hline $\begin{array}{l}\text { № } \\
3 / \Pi\end{array}$ & Показники & Характеристика & Формула розрахунку \\
\hline \multirow[t]{2}{*}{7.} & \multirow{2}{*}{$\begin{array}{l}\text { Оборотність дебіторської } \\
\text { заборгованості за товари } \\
\text { (роботи, послуги) }\left(\mathrm{K}_{\text {дз }}\right)[1]\end{array}$} & \multirow{2}{*}{$\begin{array}{c}\text { Характеризує ймовірний термін } \\
\text { реалізації продукції, необхідний } \\
\text { для забезпечення розрахун-ків за } \\
\text { кредиторською заборгованістю }\end{array}$} & $\begin{array}{c}\text { Поточна дебіторська заборго- } \\
\text { ваність за товари (роботи, послуги) }\end{array}$ \\
\hline & & & $\begin{array}{c}\text { Чистий дохід від реалізованої } \\
\text { продукції }\end{array}$ \\
\hline \multirow[t]{2}{*}{8.} & \multirow[t]{2}{*}{$\begin{array}{l}\text { Оборотність кредиторської } \\
\text { заборгованості за товари } \\
\text { (роботи, послуги) }\left(\mathrm{K}_{\text {кз }}\right)[1]\end{array}$} & \multirow{2}{*}{$\begin{array}{c}\text { Характеризує період повного } \\
\text { обороту кредиторської } \\
\text { заборгованості за товари } \\
\text { (роботи, послуги) }\end{array}$} & $\begin{array}{c}\text { Поточна кредиторська } \\
\text { заборгованість за товари (роботи, } \\
\text { послуги) }\end{array}$ \\
\hline & & & $\begin{array}{c}\text { Собівартість реалізованої } \\
\text { продукції }\end{array}$ \\
\hline \multirow[t]{2}{*}{9.} & \multirow[t]{2}{*}{$\begin{array}{l}\text { Показник обслуговування } \\
\text { боргу }\left(K_{б}\right)[1]\end{array}$} & \multirow[t]{2}{*}{$\begin{array}{c}\text { Характеризує здатність } \\
\text { підприємства обслуговувати } \\
\text { борг }\end{array}$} & $\begin{array}{c}\text { Операційний прибуток (збиток) за } \\
\text { вирахуванням фінансових витрат } \\
\text { та до відрахування амортизації }\end{array}$ \\
\hline & & & $\begin{array}{c}\text { Коротко- та довгострокові } \\
\text { зобов'язання }\end{array}$ \\
\hline \multirow[t]{2}{*}{10.} & \multirow{2}{*}{$\begin{array}{l}\text { Показник операційного } \\
\text { прибутку до відрахування } \\
\text { амортизації }\left(\kappa_{o}\right)[1]\end{array}$} & \multirow{2}{*}{$\begin{array}{c}\text { Характеризує частку } \\
\text { операційного прибутку до } \\
\text { відрахування амортизації в } \\
\text { загальному обсязі реалізації } \\
\text { продукції }\end{array}$} & $\begin{array}{c}\text { Операційний прибуток (збиток) до } \\
\text { відрахування амортизації }\end{array}$ \\
\hline & & & $\begin{array}{c}\text { Чистий дохід від реалізованої } \\
\text { продукції }\end{array}$ \\
\hline \multirow[t]{2}{*}{11.} & \multirow{2}{*}{$\begin{array}{l}\text { Коефіцієнт рентабельності } \\
\text { продажів за фінансовими } \\
\text { результатами від операційної } \\
\text { діяльності (EBIT) }\left(\kappa_{6}\right)[2]\end{array}$} & \multirow{2}{*}{$\begin{array}{c}\text { Характеризує ефективність } \\
\text { операційної діяльності } \\
\text { позичальника }\end{array}$} & $\begin{array}{c}\text { Фінансовий результат від } \\
\text { операційної діяльності }\end{array}$ \\
\hline & & & Чистий дохід від реалізації \\
\hline \multirow[t]{2}{*}{12.} & \multirow{2}{*}{$\begin{array}{l}\text { Коефіцієнт рентабельності } \\
\text { операційної діяльності за } \\
\text { EBITDA }\left(K_{7}\right)[2]\end{array}$} & \multirow{2}{*}{$\begin{array}{c}\text { Характеризує рентабельність } \\
\text { усіх операційних доходів } 3 \\
\text { EBITDA }\end{array}$} & EBITDA \\
\hline & & & $\begin{array}{l}\text { Чистий дохід від релізації + інші } \\
\text { операційні доходи }\end{array}$ \\
\hline \multicolumn{4}{|c|}{ Показники фінансового стану } \\
\hline \multirow{2}{*}{13.} & \multirow{2}{*}{$\begin{array}{c}\text { Частка власного капіталу в } \\
\text { балансі підприємства }\left(K_{\mathrm{H}}\right)[1] \text { або } \\
\text { коефіцієнт фінансової } \\
\text { незалежності }\left(\mathrm{K}_{3}\right)[2]\end{array}$} & \multirow{2}{*}{$\begin{array}{c}\text { Ступінь незалежності від } \\
\text { зовнішніх джерел фінансування }\end{array}$} & Власний капітал \\
\hline & & & Валюта балансу (актив) \\
\hline \multirow[t]{2}{*}{14.} & \multirow{2}{*}{$\begin{array}{c}\text { Частка оборотних активів, } \\
\text { непокритих поточними } \\
\text { зобов’язаннями }\left(\mathrm{K}_{\mathrm{M}}\right)[1]\end{array}$} & \multirow[t]{2}{*}{$\begin{array}{c}\text { Ступінь маневреності робочого } \\
\text { капіталу }\end{array}$} & $\begin{array}{l}\text { Оборотні активи за вирахуванням } \\
\text { поточних зобов'язань і забезпечень }\end{array}$ \\
\hline & & & Валюта балансу (актив) \\
\hline \multirow[t]{2}{*}{15.} & \multirow{2}{*}{$\begin{array}{l}\text { Покриття власним капіталом } \\
\text { фінансової заборгованості } \\
\text { підприємства (Кв) [1] }\end{array}$} & \multirow{2}{*}{$\begin{array}{c}\text { Спроможність покриття } \\
\text { власним капіталом коротко- та } \\
\text { довгострокових зобов’язань }\end{array}$} & Власний капітал \\
\hline & & & $\begin{array}{c}\text { Коротко- та довгострокові } \\
\text { зобов'язання } \\
\end{array}$ \\
\hline \multirow[t]{2}{*}{16.} & \multirow[t]{2}{*}{$\begin{array}{l}\text { Швидка ліквідність балансу } \\
\text { підприємства }\left(\mathrm{K}_{ш}\right)[1]\end{array}$} & \multirow{2}{*}{$\begin{array}{c}\text { Здатність підприємства } \\
\text { оперативно покривати потреби } \\
\text { в ліквідності }\end{array}$} & $\begin{array}{c}\text { Дебіторська заборгованість за } \\
\text { продукцію, гроші та їх еквіваленти }\end{array}$ \\
\hline & & & $\begin{array}{c}\text { Поточні зобов'язання і } \\
\text { забезпечення } \\
\end{array}$ \\
\hline \multirow[t]{2}{*}{17.} & \multirow{2}{*}{$\begin{array}{l}\text { Загальна ліквідність балансу } \\
\text { підприємства }\left(\mathrm{K}_{3}\right)[1] \text { або } \\
\text { Коефіцієнт покриття }\left(\mathrm{K}_{1}\right) \text { [2] }\end{array}$} & Здатність підприємства & Оборотні активи \\
\hline & & $\begin{array}{c}\text { покривати короткострокові } \\
\text { зобов'язання за рахунок } \\
\text { оборотних активів } \\
\end{array}$ & $\begin{array}{c}\text { Поточні зобов’язання і } \\
\text { забезпечення }\end{array}$ \\
\hline 18. & Показник частки & Характеризує рівень активів, & Неопераційні активи \\
\hline & $\begin{array}{l}\text { неопераційних елементів } \\
\text { балансу }\left(K_{\text {на }}\right)[1]\end{array}$ & $\begin{array}{c}\text { що не мають прямого } \\
\text { відношення до операційної } \\
\text { діяльності підприємства }\end{array}$ & Валюта балансу (актив) \\
\hline 19. & Коефіцієнт покриття & Характеризує рівень & Власний капітал \\
\hline & $\begin{array}{l}\text { необоротних активів власним } \\
\text { капіталом }\left(\mathrm{K}_{4}\right)[2]\end{array}$ & $\begin{array}{c}\text { фінансування необоротних } \\
\text { (довгострокових) активів за } \\
\text { рахунок власного капіталу } \\
\text { бенефіціара }\end{array}$ & Необоротні активи \\
\hline
\end{tabular}

*Складено авторами на основі даних [1;2] 
На нашу думку, в першу чергу, необхідно зосередити увагу на динаміці показників ділової активності, зокрема: середньому терміні погашення дебіторської заборгованості $\left(K_{\text {дз }}\right)$ та оборотності кредиторської заборгованості $\left(\mathrm{K}_{\text {к3}}\right)$, оскільки прискорення оборотності $є$ одним 3 факторів зростання рентабельності. Але враховуючи, що зростання рентабельності може бути обумовлено збільшенням ризику від певної діяльності підприємства, то при уповільненні ділової активності (оборотності) та наявності позитивних тенденцій рентабельності підприємству можуть загрожувати перспективні проблеми 3 виконанням своїх кредиторських зобов'язань. Таким чином, проведення фінансового моніторингу стану підприємств будівельного сектору створює систему раннього виявлення кризи, яка потенційно загрожує кожному підприємству та знижує його кредитоспроможність.

На нашу думку, з метою прогнозування ймовірності непогашення позики, якою вже користується суб'єкт господарювання, при аналізі показників достатності робочого капіталу $\left(K_{\mathrm{pк}}\right)$ та оборотності кредиторської заборгованості $\left(\mathrm{K}_{\text {к3 }}\right)$, складовою яких $\epsilon$ собівартість, необхідно враховувати розбіжності в часі процесів будівництва об'єктів та звітного періоду, а також особливості будівельної продукції як товара: тривалий термін виробничого циклу; вплив природно-кліматичних умов, що висуває необхідність врахування пов'язаних 3 цим ризиків; сезонний характер виробництва, що впливає на нерівномірність використання трудових ресурсів, техніки [3, с.289]. Додатково можна проаналізувати питому вагу постійних витрат в собівартості робіт, адже зниження собівартості робіт прямопропорційно впливає на збільшення прибутку підприємства [4, с.110].

Поряд 3 цим вважаємо доцільним доповнення аспектів фінансового моніторингу в оцінці короткострокового кредитного ризику критеріями стратегічних перспектив розвитку підприємств в оцінці рівня довгострокового кредитного ризику - моніторингом дотримання будівельними підприємствами критеріїв соціальної відповідальності. Встановлення діапазонів та зон соціальної відповідальності будівельного підприємства $\left[\begin{array}{lll}5, & \text { с. } & 168\end{array}\right]$, недосягнення якої робить суб'єкт господарювання соціально невідповідальним (мінімально необхідною умовою господарювання на засадах соціальної відповідальності $\epsilon$ досягнення точки соціальної відповідальності) виявляється, на нашу думку, важливим напрямком удосконалення методики оцінки рівня ділової репутації та кредитоспроможності будівельних підприємств.

На сучасному етапі розвитку галузі українські забудовники, з одного боку, роблять спроби розробки конкретних підходів до соціальної відповідальності, впровадження міжнародних принципів прозорості бізнесу, екологічної безпеки, трудових відносин i підтримки суспільства. 3 іншого боку, вони вимушені здійснювати діяльність в умовах кризового стану економіки і соціальної сфери, що ускладнює їх діяльність та зменшує економічну безпеку [6, с.50]. Таким чином, важливим фактором впливу на економічну безпеку будівельних підприємств вважається дотримання ними рівня корпоративної соціальної відповідальності. Соціальна відповідальність $є$ відповідальністю організації за вплив своїх рішень та діяльності (продукти, послуги, процеси) на суспільство й навколишне природне середовище, що реалізується через прозору та етичну поведінку, яка допомагає сталому розвитку, здоров'ю і добробуту суспільства; зважає на очікування зацікавлених сторін; не суперечить відповідному законодавству й міжнародним нормам поведінки та практикується у її відносинах [5, с.163].

Процес оцінки соціальної відповідальності підприємств як важливий фактор ефективного управління впливом соціальних показників на рівень ділової репутації здійснюється за допомогою кількісних та якісних показників-індикаторів рівня соціальноорієнтованого управління бізнесом. Вибір того чи іншого інструментарію залежить від розуміння самої сутності соціальної відповідальності підприємства суб'єктами оцінки, галузевою та іншою специфікою діяльності об'єкта. Систему показників для експертного та бального оцінювання рівня соціальної відповідальності будівельного підприємства на основі методичного підходу, що передбачає комбінацію якісних та кількісних показників із виділенням специфічних галузевих показників соціальної відповідальності, характерних для будівельних підприємств, наведено в таблиці 2.

Висновки та перспективи подальших досліджень. Будівельний бізнес $€$ високомаржинальним, але легко піддається різноманітним економічним коливанням. Для успішної роботи банків 3 проведення якісного аналізу кредитоспроможності потенційних позичальників будівельного сектору стає необхідним вдосконалення методичних підходів до визначення рівня інтегральних показників 
Таблиця 2

Система показників соціальної відповідальності будівельних підприсмств*

\begin{tabular}{|c|c|c|}
\hline \multirow{2}{*}{$\begin{array}{l}\text { № } \\
\text { 3/ח }\end{array}$} & \multicolumn{2}{|c|}{ Показники } \\
\hline & Кількісні & Якісні \\
\hline 1. & $\begin{array}{c}\text { Відношення кількості робочих місць, що } \\
\text { відповідають вимогам охорони праці та техніки } \\
\text { безпеки до загальної кількості робочих місць }\end{array}$ & Наявність колективного договору \\
\hline 2. & $\begin{array}{c}\text { Відношення суми витрат на соціальний захист } \\
\text { та покращення умов праці до загальної суми } \\
\text { прибутку підприємства }\end{array}$ & $\begin{array}{c}\text { Дотримання законодавства про добросовісну } \\
\text { конкуренцію }\end{array}$ \\
\hline 3. & Коефіцієнт виробничого травматизму & Пропаганда соціальної відповідальності \\
\hline 4. & $\begin{array}{c}\text { Відношення суми витрат на навчання та } \\
\text { розвиток персоналу до загальної суми } \\
\text { операційних витрат підприємства }\end{array}$ & Антикорупційна діяльність \\
\hline 5. & $\begin{array}{c}\text { Відношення середнього розміру заробітної } \\
\text { плати працівників підприємства до середнього } \\
\text { по галузі }\end{array}$ & Якість системи корпоративного управління \\
\hline 6. & $\begin{array}{c}\text { Частка витрат на оплату праці в собівартості } \\
\text { продукції }\end{array}$ & Регулярний збір соціальної звітності \\
\hline 7. & $\begin{array}{c}\text { Відношення суми сплачених податків до } \\
\text { загальної суми нарахованих податків }\end{array}$ & Реалізація екологічних програм \\
\hline 8. & $\begin{array}{c}\text { Відношення простроченої кредиторської } \\
\text { заборгованості перед діловими партнерами до } \\
\text { загальної суми кредиторської заборгованості } \\
\text { перед діловими партнерами }\end{array}$ & Участь у програмі соціального розвитку регіону \\
\hline 9. & $\begin{array}{c}\text { Кількість отриманих рекламацій та претензій } \\
\text { від споживачів }\end{array}$ & Благодійність та спонсорство \\
\hline
\end{tabular}

*Складено авторами на основі даних [7, с.271-272; 5, с. 164]

господарської д діяльності підприємств будівельного сектору України. На сучасному етапі здебільшою мірою приділяється увага фінансовим показникам, що відображають стан капіталу підприємств, здатність будівельної компанії до отримання прибутку, піi ділову активність. Такий підхід є доцільним для моніторинту поточного стану підприємства, але встановлення стратегічних пріоритетів розвитку компанії безумовно потребує дослідження іiі економічної безпеки дотриманням потреб суспільства та соціальної відповідальності.

Перспективою подальших наукових досліджень $\epsilon$ аналіз практичних результатів запропонованих підходів до комплексної оцінки кредитоспроможності позичальників будівельного сектору в Україні.

\section{ПЕРЕЛІК ВИКОРИСТАНИХ ДЖЕРЕЛ}

1. Положення про визначення банками України розміру кредитного ризику за активними банківськими операціями 30.06.2016 № 351 Офіційний сайт Національного банку України / [Електронний ресурс]. - Режим доступу: http://zakon5.rada.gov.ua/laws/show/v0351500-16/paran18\#n18

2. Наказ Міністерства фінансів України від 14.07.2016 № 616 «Про затвердження Порядку проведення оцінки фінансового стану потенційного бенефіціара інвестиційного проекту» [Електронний ресурс]. - Режим доступу: http://zakon.rada.gov.ua/laws/show/z1095-16.

3. Шевчук Н.С. Методичні аспекти управлінського аналізу сучасних будівельних підприємств [Текст]/ Н.С.Шевчук// Науковий вісник Ужгородського університету. - 2018. - № 1(51). - С.288-291

4. Нікульникова Т.Г. Аналіз фінансового стану як інструмент фінансово-господарського аудиту на прикладі підприємств будівельної галузі [Текст]/ Т.Г. Нікульникова// Вісник Криворізького економічного інституту КНУ. - 2013. - № 2. - C.107-110

5. Смачило В.В., Баляба В.О. Оцінка соціальної відповідальності будівельних підприємств [Текст]/ В.В.Смачило, В.О. Баляба// Економіка: реалії часу. - 2015. - № 6(22). - С.162-169

6. Гриценко О.С., Запєчна Ю.О., Бородавко М.В. Вплив на економічну безпеку будівельного підприємства рівня корпоративної соціальної відповідальності [Текст]/ О.С. Гриценко, Ю.О. Запєчна, М.В. Бородавко// Будівельне виробництво. - 2015. - № 59. - С.49-51

7. Плахотнікова К.В. Економіко-математичні методи аналізу корпоративної соціальної відповідальності будівельних компаній України [Текст]/ К.В. Плахотнікова// Науковий вісник будівництва. - 2017. - Т.87, № 1. C.271-274. 


\section{REFERENCES}

1. Polozhennya pro vyznachennya bankamy Ukrayiny rozmiru kredytnoho ryzyku za aktyvnymy bankivs'kymy operatsiyamy [Regulation on determination by banks of Ukraine of the size of credit risk under active banking operations] (2016, June 30). Ofitsiynyy sayt Natsional'noho banku Ukrayiny - Official site of the National Bank of Ukraine. Retrieved from: http://zakon5.rada.gov.ua/laws/show/v0351500-16/paran18\#n18 [in Ukrainian].

2. Nakaz Ministerstva finansiv Ukrayiny «Pro zatverdzhennya poryadku provedennya otsinky finansovoho stanu potentsiynoho benefitsiara investytsiynoho proektu» [Order of the Ministry of Finance of Ukraine «On approval of the procedure for assessing the financial condition of a potential beneficiary of an investment project»]. (2016, July 14). Retrieved from: http://zakon.rada.gov.ua/laws/show/z1095-16 [in Ukrainian].

3. Shevchuk, N.S. (2018). Metodychni aspekty upravlins'koho analizu suchasnykh budivel'nykh pidpryyemstv [Methodical aspects of managerial analysis of modern construction enterprises]. Naukovyy visnyk Uzhhorods'koho universytetu - Scientific bulletin of Uzhgorod university, 1(51), 288-291 [in Ukrainian].

4. Nikul'nykova, T.H. (2013). Analiz finansovoho stanu yak instrument finansovo-hospodars'koho audytu na prykladi pidpryyemstv budivel'noyi haluzi [Analysis of the financial state as an instrument of financial and economic audit on the example of construction industry enterprises]. Visnyk Kryvoriz'koho ekonomichnoho instytutu KNU Bulletin of the Kryvy Rih Economic Institute of the KNU, 2, 107-110 [in Ukrainian].

5. Smachylo, V.V., \& Balyaba, V.O. (2015). Otsinka sotsial'noyi vidpovidal'nosti budivel'nykh pidpryyemstv [Assessment of social responsibility of construction enterprises]. Ekonomika: realiyi chasu - Economics: realities of time, 6(22), 162-169 [in Ukrainian].

6. Hrytsenko, O.S., \& Zapyechna, Yu.O., \& Borodavko, M.V. (2015). Vplyv na ekonomichnu bezpeku budivel'noho pidpryyemstva rivnya korporatyvnoyi sotsial'noyi vidpovidal'nosti [Influence on the economic safety of a construction company on the corporate social responsibility level]. Budivel'ne vyrobnytstvo - Construction production, 59, 49-51 [in Ukrainian].

7. Plakhotnikova, K.V. (2017). Ekonomiko-matematychni metody analizu korporatyvnoyi sotsial'noyi vidpovidal'nosti budivel'nykh kompaniy Ukrayiny [Economical and mathematical methods of analysis of Ukraine's corporate construction companies' social responsibility]. Naukovyy visnyk budivnytstva - Scientific bulletin of construction, 1, 271-274 [in Ukrainian].

Одержано 31.08.2018 p. 